\title{
Use of Ca-alginate immobilized Pseudomonas aeruginosa for repeated batch and continuous degradation of Endosulfan
}

\author{
Vijayalakshmi Pradeep $^{1} \cdot$ Usha Malavalli Subbaiah $^{1}$
}

Received: 22 November 2015 / Accepted: 25 May 2016/Published online: 6 June 2016

(c) The Author(s) 2016. This article is published with open access at Springerlink.com

\begin{abstract}
The current investigation is taken up with the aim of studying repeated batch and continuous degradation of Endosulfan, using Ca-alginate immobilized cells of Pseudomonas aeruginosa isolated from an agricultural soil. The work involves the study of genes and enzymes involved in the degradation of the pesticide and was carried out with an objective of reducing the toxicity of Endosulfan by degrading it to less toxic metabolites. The long-term stability of Endosulfan degradation was studied during its repeated batch degradation, carried out over a period of 35 days. Immobilized cells of Ps. aeruginosa were able to show $60 \%$ degradation of Endosulfan at the end of the 35 th cycle with a cell leakage of $642 \times 10^{4} \mathrm{Cfu} / \mathrm{mL}$. During continuous treatment, with $2 \%$ concentration of Endosulfan, $100 \%$ degradation was recorded up to $100 \mathrm{~mL} / \mathrm{h}$ flow rate and with $10 \%$ concentration of the Endosulfan, and 100 and $85 \%$ degradation was recorded at $20 \mathrm{~mL} / \mathrm{h}$ flow rate and $100 \mathrm{~mL} / \mathrm{h}$ flow rate, respectively. After degradation of Endosulfan, products were extracted from a large amount of spent medium using two volumes of ethyl acetate and subjected to the LC-MS analysis. Endosulfan lactone and Endosulfan ether were the products of degradation detected by the LCMS analysis. Plasmid curing experiments indicated that genes responsible for the degradation of Endosulfan are present on the chromosome and not on the plasmid, as growth of Ps. aeruginosa was observed on modified non-sulfur medium with Endosulfan after the plasmid was cured with ethidium bromide. The results of PCR indicated that there is no amplified product
\end{abstract}

Usha Malavalli Subbaiah

bg.ushams@gmail.com

1 Department of Life Sciences, SGS, Jain University, JC Road, Bangalore 560011, India of $\sim 1350$ bp expected for esd gene, in Ps. aeruginosa, although there were some non-specific bands. Enzymatic degradation studies indicated that the enzymes involved in the degradation of Endosulfan are intracellular. With this investigation, it was indicated that immobilized cells of $P s$. aeruginosa have the potential to be used in the bioremediation of water contaminated with Endosulfan.

Keywords Pseudomonas aeruginosa $\cdot$ Ca-alginate immobilization - Repeated batch degradation . Continuous degradation - Plasmid curing, PCR analysis . Intracellular degradative enzymes

\section{Introduction}

Endosulfan is a cyclodiene organo-chlorine. It is a mixture of the two isomers, $\alpha$ and $\beta$-Endosulfan. Both of these isomers are toxic, with the $\alpha$-isomer being more toxic than $\beta$-isomer (JenNi et al. 2005). It is used extensively throughout the world as a contact and stomach insecticide and as an acaricide on field crops, such as cotton, paddy, sorghum, oilseeds, coffee, vegetables, and fruit crops (Lee et al. 1995; Kullman and Matsumura 1996). It is used to control chewing and sucking insects, such as Colorado beetle, flea beetle, cabbage worm aphids and leaf hopper (Goebel 1982; Hoechst 1990). Endosulfan has been implicated in mammalian gonadal toxicity (Sinha et al. 1997), genotoxicity (Chaudhuri et al. 1999), and neurotoxicity (Paul and Balasubramaniam 1997).

Biodegradation of pesticides can be carried out using free as well as immobilized cells. Research has suggested that this higher productivity results from cellular or genetic modifications induced by immobilization. Evidences indicate that the immobilized cells are much more tolerant to

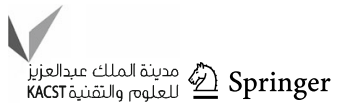


perturbations in the reaction environment, are less susceptible to toxic substances make immobilized cell systems, and are particularly attractive for the treatment of toxic substances, such as pesticides (Manohar et al. 2001; Kim et al. 2002; Jianlong et al. 2002). Various materials have been selected as carriers for the immobilization of microorganisms to treat wastewater, including network polymers, alginate, polyacylamide hydrazide, calcium alginate, activated pumice, and activated carbon (Pai et al. 1995; Murakami et al. 2003; Pazarlioglu and Telefoncu 2005; Rahman et al. 2006; Karigar et al. 2006).

There are reports on the biodegradation of pesticides using immobilized cells (Ha et al. 2009; Yáñez-Ocampo et al. 2011; Abdel-Razek et al. 2013) and immobilized enzymes (Richins et al. 2000; Mansee et al. 2005). However, studies on the degradation of Endosulfan using immobilized cells are limited (Jo et al. 2010).

Aerobic bacteria degrading Endosulfan were isolated from contaminated sludge by Yu et al. (2012). LD-6 was one of the isolates, which was identified as Stenotrophomonas spp. Cell crude extract of strain LD-6 could metabolize Endosulfan rapidly, and degradative enzymes were intracellular distributed and constitutively expressed. Shivaramaiah and Kennedy (2006) studied the biodegradation of Endosulfan by a soil bacterium S3 which consistently degraded Endosulfan. Endosulfan degradation results indicated that the enzyme system responsible was probably a mono-oxygenase, converting Endosulfan to Endosulfan sulfate. Katayama and Matsumura (1993) showed that the cultures of Trichoderma harzianum were capable of producing Endosulfan diol as a principal metabolite. They suggested that a hydrolytic enzyme sulfatase is responsible for the indirect formation of Endosulfan diol by the hydrolysis of Endosulfan sulfate.

Genes involved in the degradation of Endosulfan have also been studied by many researchers (Weir et al. 2006; Verma et al. 2011; Vijaiyan and Rajam 2013). Sutherland et al. (2002a) reported the role of esd gene in degrading Endosulfan.

The batch degradation study using free cells and Caalginate immobilized cells of Ps. aeruginosa JX204836 isolated from an agricultural field was carried out by us and reported in our earlier publication, where immobilized cells showed a better degradation potential at higher pesticide concentrations compared to free cells (Vijayalakshmi and Usha 2012). The present study is taken up with the objective of studying the continuous and repeated batch degradation of Endosulfan using immobilized cells of $P s$. aeruginosa, isolated from a soil amended with the pesticide. The research also involves the study of genes and the enzymes involved in the degradation of Endosulfan, so that the enzymes could also be immobilized and utilized for the process of bioremediation of waters contaminated with endosulfan.

\section{Materials and methods}

\section{Pesticide and other chemicals}

Commercial-grade insecticide Endosulfan (35\% EC) was procured from a pesticide selling shop in Bangalore. Other chemicals were procured from Hi-Media Pvt. Ltd. Mumbai. The Endosulfan standard was provided as a kind gift by IIHR, Bangalore. Other chemicals used in the preparation of modified non-sulfur medium (Siddique et al. 2003), $\mathrm{K}_{2} \mathrm{HPO}_{4}, \mathrm{KH}_{2} \mathrm{PO}_{4}, \mathrm{NH}_{4} \mathrm{Cl}, \mathrm{MgCl}_{2} \cdot 6 \mathrm{H}_{2} \mathrm{O}, \mathrm{CaCO}_{3}, \mathrm{FeCl}_{2}$ $4 \mathrm{H}_{2} \mathrm{O}$, and trace element solution, the preparation of phosphate buffer, chemicals used for the immobilization and estimation of Endosulfan, and the solvent Ethyl acetate and methanol used in the extraction and dissolution of endosulfan were of analytical grade. These were procured from Sd Fine Chemicals Ltd., Mumbai, Maharashtra, India and Himedia Laboratories Pvt. Ltd., Mumbai, Maharashtra, India. For the Endosulfan estimation procedure, double distilled deionised water was used.

\section{Bacterial culture}

In the present study, Ps. aeruginosa, isolated from an agricultural field with the previous history of pesticide application, identified based on nucleotide sequence and deposited in the gene bank with the accession number JX204836 was used.

\section{Growth of the culture}

Pseudomonas aeruginosa was grown in modified non-sulfur medium (Siddique et al. 2003) containing $2.5 \%$ Endosulfan under optimized conditions. After incubation, the bacterial cells were harvested by centrifugation at $10,000 \mathrm{rpm}$ for $15 \mathrm{~min}$. These cells after washing with $0.01 \mathrm{M}$ Phosphate buffer $(\mathrm{pH}$ 7.0) were used for the immobilization experiments.

\section{Immobilization in Ca-alginate}

Ca-alginate entrapment of Ps. aeruginosa was performed according to the method of Bettman and Rehm (1984). Sodium alginate $(3 \% \mathrm{w} / \mathrm{v})$ was dissolved in distilled water and autoclaved at $121^{\circ} \mathrm{C}$ for $15 \mathrm{~min}$. Fresh bacterial pellet $(3 \% \mathrm{w} / \mathrm{v})$ of Ps. aeruginosa was mixed in $100 \mathrm{~mL}$ sterilized sodium alginate solution. This mixture was extruded drop by drop into a cold sterile $0.2 \mathrm{M}$ Calcium chloride solution using a sterile syringe. Gel beads of approximately 
$2 \mathrm{~mm}$ diameter were obtained. The beads were hardened by resuspending in a fresh $0.2 \mathrm{M}$ Calcium chloride solution for $2 \mathrm{~h}$ with gentle agitation. Finally, these beads were washed with sterile distilled water and stored in $0.2 \mathrm{M}$ Calcium chloride at $4{ }^{\circ} \mathrm{C}$ until further use.

\section{Repeated batch degradation of Endosulfan}

Repeated batch degradation studies were performed to observe the long-term stability of Ca-alginate immobilized $P$ s. aeruginosa culture degrading Endosulfan. After each cycle of incubation for $24 \mathrm{~h}$ at $150 \mathrm{rpm}$ shaking speed and at $37^{\circ} \mathrm{C}$, the spent medium was decanted, and beads were washed with sterile distilled water and transferred into a fresh sterile minimal mineral salt medium (Manohar and Karegoudar 1998) containing $2 \%$ Endosulfan.

The remaining amount of Endosulfan in the media after incubation was estimated by spectrophotometric analysis, as described by Venugopal and Sumalatha (2011). At intervals of 5 days/cycles, the stability of beads was monitored, and cell leakage was recorded as $\mathrm{Cfu} / \mathrm{mL}$ values by plating $1 \mathrm{~mL}$ of spent medium onto nutrient agar medium.

\section{Design of bioreactor for continuous treatment}

A schematic representation of the cylindrical glass column used as the bioreactor for continuous degradation of Endosulfan is shown in Fig. 1 . The column $(4 \times 50 \mathrm{~cm}$ volume $650 \mathrm{~mL}$ ), as shown in Fig. 2, with inlet and outlet facilities was used. The bottom of the column was packed with glass wool ( $4 \mathrm{~cm}$ diameter) followed by a porous glass frit. Then, the reactor was packed with the Ca-alginate immobilized culture of Ps. aeruginosa for the degradation of the pesticide to a height of $30 \mathrm{~cm}$. The reactor was attached to a reservoir containing minimal mineral salts medium (Manohar and Karegoudar 1998) with Endosulfan. The medium after pesticide degradation was continuously removed from the side arm situated just above the packed bed.

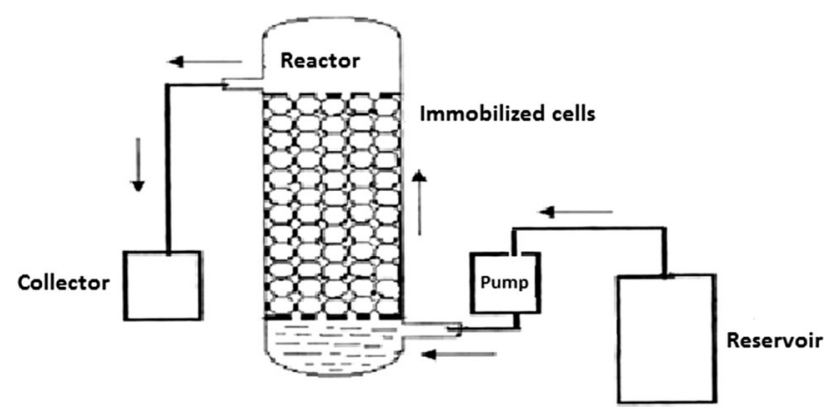

Fig. 1 Schematic diagram of the bioreactor

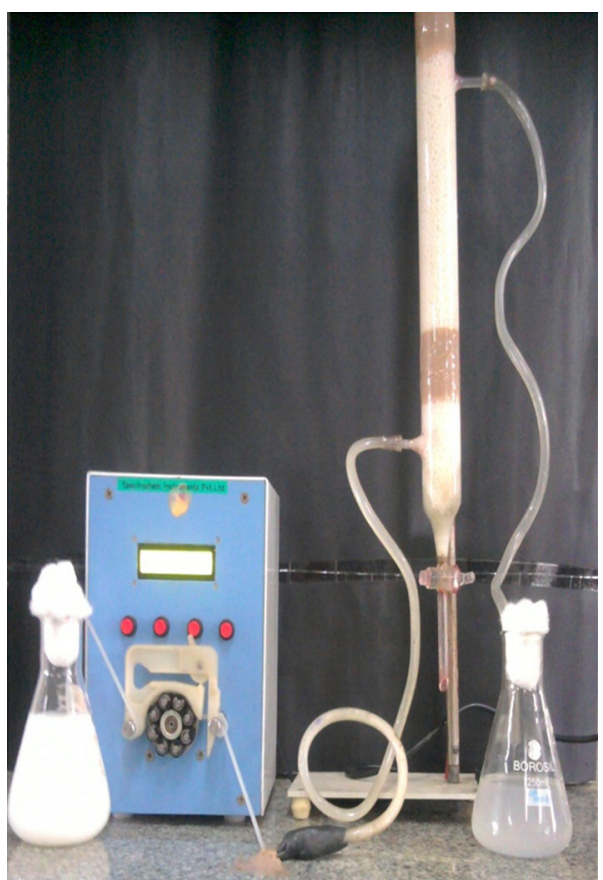

Fig. 2 Reactor packed with Ca-alginate immobilized Ps. aeruginosa

The detention time (dt) of degradation was calculated by the following formula:

Detention time: void volume/flow rate $(\mathrm{mL} / \mathrm{h})$

Degradation rate $(R)=\left(C_{\mathrm{i}}-C_{\mathrm{e}}\right) \times \mathrm{D}$

where $C_{\mathrm{i}}=$ concentration of the pesticide in the influent $C_{\mathrm{e}}=$ Concentration of the pesticide in the effluent

$D=$ Dilution rate $=$ flow rate $(\mathrm{mL} / \mathrm{h}) /$

void volume of the reactor $(\mathrm{mL})$

where flow rate is the quantity of the sample passing through the column, expressed as $\mathrm{mL} / \mathrm{h}$.

\section{Continuous degradation of Endosulfan}

The continuous treatment of Endosulfan was carried out in a continuous flow reactor. The reactor was filled with $\mathrm{Ca}$ alginate immobilized Ps. aeruginosa for the degradation of Endosulfan. Degradation process was carried out by continuous supply of sterile minimal mineral salts medium containing Endosulfan with the help of peristaltic pump (Miclins PP10-4C, India). Flow rates ranged from $20 \mathrm{~mL} / \mathrm{h}$ to $100 \mathrm{~mL} / \mathrm{h}$ with varying concentrations of Endosulfan $(2-10 \%)$.

\section{Estimation of Endosulfan}

Estimation of Endosulfan was carried out according to Venugopal and Sumalatha (2011). Acid reagent was 
prepared by dissolving $304 \mathrm{~g}$ of $\mathrm{p}$-Toluene sulfonic acid in $1 \mathrm{~L}$ of isopropanol plus $200 \mathrm{~mL}$ of water (Raju and Gupta 1991). Aliquotes of one $\mathrm{mL}$ of extracts were dried, and to the aliquote, $5 \mathrm{~mL}$ of acid reagent was added. To this, $1 \mathrm{~mL}$ of $2 \%$ alcoholic potassium hydroxide and $10 \mathrm{~mL}$ of $0.1 \mathrm{~N}$ of hydrogen peroxide were then added. The sulfur dioxide liberated was oxidized to sulfate and allowed to react with $0.1 \mathrm{~mL}$ of $0.1 \%$ solution of diphenyl amine to give a light violet colour. The solution was kept aside for $5 \mathrm{~min}$, and the absorbance was measured at $605 \mathrm{~nm}$ against reagent blank. The absorbance corresponding to the bleached colour which in turn corresponds to the analyte Endosulfan concentration was obtained by subtracting the absorbance of the blank solution from that of test solution.

\section{Estimation of percent degradation}

Percent degradation was calculated using the given formula:

Percent degradation $=\left[\left(C_{0}-C t\right) / C_{0}\right] \times 100$

where $C_{0}=$ initial concentration and $C t=$ concentration at time ' $t$ '.

Degradation efficiency is defined as the ability of $P s$. aeruginosa to degrade the pesticide and is calculated based on percent degradation as shown in Eq. (4).

\section{Identification of degradation products}

After degradation of Endosulfan using Ca-alginate immobilized Ps. aeruginosa, the products were extracted from a large amount of spent medium using two volumes of ethyl acetate, dried, and finally mixed with methanol and sent to Indian Institute of Science, Bangalore for the LC-MS analysis.

\section{LC-MS analysis conditions}

HPLC analyses were performed using Thermo Finnigan Survey. The column used was a BDS HYPERSIL C18 (Reverse Phase) with length $250 \mathrm{~mm}$, I.D. $4.6 \mathrm{~mm}$, and particle size $5 \mu \mathrm{m}$. Detection was done with UV at 254 and $280 \mathrm{~nm}$. The detector used was HPLC PDA/UV detector; with ambient temperature and injection volume of $10 \mu \mathrm{L}$. An isocratic eluent with Acetonitrile:Water in the ratio 70:30 was used. The flow rate was $0.2 \mathrm{~mL} / \mathrm{min}$ with a run time of $60.00 \mathrm{~min}$. HPLC grade acetonitrile from the company Merck was used. The water used as a part of the isocratic eluent was milli-Q water.

Mass spectroscopy (MS) was performed using Thermo LCQ Deca XP MAX. The software used was Xcalibur. Conditions used for MS were-probe/source voltage of $4.5 \mathrm{kV}$; mode of ionization +ve mode; mass range
50-500 $\mathrm{m} / \mathrm{z}$; sheath gas flow (arbitrary units): 40.00; auxiliary/sweep gas flow (arbitrary units): 20.00; source type: ESI (Electro Spray Ionization); sample trey temperature: $5{ }^{\circ} \mathrm{C}$; column oven temp: $40{ }^{\circ} \mathrm{C}$; capillary temperature: $275^{\circ} \mathrm{C}$; capillary voltage: $16.00 \mathrm{~V}$; nebulisation gas flow: helium at $1 \mathrm{~mL} / \mathrm{min}$ approximately. The helium in the mass analyzer cavity was maintained at $0.1 \mathrm{~Pa}\left(10^{-3}\right)$.

\section{Plasmid isolation and plasmid curing}

To know the number of plasmids present and to find out whether the genes responsible for the production of enzymes involved in the degradation of Endosulfan are present on the genomic DNA or on the extra chromosomal DNA; plasmid isolation and plasmid curing experiments were performed. The culture Ps. aeruginosa degrading Endosulfan was grown in Luria-Bertani (LB) broth for 24 h. Plasmid DNA was extracted using the alkaline lysis method (Sambrook and Russell 2001) from the cell pellet of the culture. The extracted plasmid DNA band was observed by agarose gel electrophoresis.

Ps. aeruginosa degrading Endosulfan was inoculated into $100 \mathrm{~mL}$ nutrient broth medium and incubated for $24 \mathrm{~h}$ under shaking speed of $150 \mathrm{rpm}$. After $24 \mathrm{~h}$ of incubation, $1 \mathrm{~mL}$ of broth was inoculated into fresh nutrient broth with $300 \mu \mathrm{g} /$ $\mathrm{mL}$ of Ethidium bromide. Plasmid DNA was extracted (Sambrook and Russell 2001) and subjected to $1 \%$ agarose gel electrophoresis. The procedure was repeated up to 6 days. Plasmid cured culture was checked for its efficiency in degrading Endosulfan by plating $1 \mathrm{~mL}$ of culture on modified non-sulfur medium (Siddique et al. 2003).

\section{Genomic DNA isolation and PCR analysis}

Ps. aeruginosa culture degrading Endosulfan was subjected to the PCR analysis, which was outsourced from Bhat Bio-tech India Private Limited, Bangalore. The genomic DNA was isolated from Ps. aeruginosa using genomic DNA extraction Kit. The pellet from $1.5 \mathrm{~mL}$ of overnight culture was resuspended in $500 \mu \mathrm{L}$ of lysis buffer and incubated at $37^{\circ} \mathrm{C}$ for $1 \mathrm{~h}$ to lyse the cells. Genomic DNA was then extracted by Phenol/Chloroform. DNA from the aqueous phase was precipitated with isopropanol, washed with $70 \%$ Ethanol, and air dried. The DNA pellet was dissolved in $50 \mu \mathrm{L}$ of nuclease free water. $1 \mu \mathrm{L}$ of the genomic DNA was used to analyze on $0.5 \%$ Agarose gel electrophoresis.

Amplification of the esd genes was performed using the following primer pairs Sutherland et al. 2002a)

esd Forward primer: 5'-CCATATGACCCGACAGCTA CACCTC-3'

esd Reverse Primer: 5'-CAGATCTATTACGCGACCG CGTGCGCCA-3' 
The amplification was carried out in a Master cycler $^{\circledR}$ Thermocycler (Eppendorf, Germany) using the following program. For the amplification of esd gene, the initial denaturation of $95^{\circ} \mathrm{C}$ for 2 min followed by 35 cycles of denaturation at $94{ }^{\circ} \mathrm{C}$ for $30 \mathrm{~s}$, annealing at $63{ }^{\circ} \mathrm{C}$ for $45 \mathrm{~s}$ and extension at $72{ }^{\circ} \mathrm{C}$ for $1 \mathrm{~min}$ was used. The final extension was carried out at $72{ }^{\circ} \mathrm{C}$ for $10 \mathrm{~min} .10 \mu \mathrm{L}$ of PCR product was analyzed on $0.8 \%$ Agarose gel electrophoresis. The kit that was used for the analysis was from Bhat Bio-tech India Private Limited, Bangalore.

\section{Enzymatic degradation of Endosulfan}

Experiment was conducted to find out whether the enzymes involved in the degradation of Endosulfan by Ps. aeruginosa were extracellular, membrane bound, or intracellular.

Pseudomonas aeruginosa was grown in $100 \mathrm{~mL}$ modified non-sulfur medium (Siddique et al. 2003) under optimized conditions. The cells of the culture from the medium were harvested during mid logarithmic phase by centrifugation at $10,000 \mathrm{rpm}$ for $20 \mathrm{~min}$ at $4{ }^{\circ} \mathrm{C}$. Supernatant of the culture was stored separately. The cell pellet of $P S$. aeruginosa was washed with $1 \mathrm{~mL}$ of $0.05 \mathrm{M}$ phosphate buffer (pH 6.8) (Yu et al. 2012). Buffer wash of the culture was collected separately. The cell pellet obtained was resuspended in $1 \mathrm{~mL}$ of the buffer. The cells were lysed using $1 \mathrm{~mL}$ of freshly prepared lysozyme solution $(10 \mathrm{mg} /$ $\mathrm{mL}$ ) in $10 \mathrm{mM}$ Tris-HCl, pH 8.0 (Sambrook et al. 1989). The supernatant, buffer wash, and cell lysate were refrigerated until further use. Enzymatic degradation of Endosulfan was studied with all the three fractions, i.e., supernatant, buffer wash, and cell lysate. The protein content of each fraction was determined by the Bradford's method (1976).

Enzymatic degradation of Endosulfan was carried out according to $\mathrm{Yu}$ et al. (2012). The reaction mixture was taken in triplicates with $1 \mathrm{~mL}$ of $0.05 \mathrm{M}$ phosphate buffer (pH 6.8) containing $200 \mu \mathrm{L}$ of supernatant and $50 \mathrm{mg} / \mathrm{L}$ of Endosulfan. The reaction mixture was incubated at $30{ }^{\circ} \mathrm{C}$ for $45 \mathrm{~min}$. After the incubation, the residual Endosulfan was quantified spectrophotometrically at $605 \mathrm{~nm}$ according to Venugopal and Sumalatha (2011). The amount of Endosulfan degraded was calculated. Similar experiments were carried out with $200 \mu \mathrm{L}$ of the buffer wash and cell lysate separately, and the degradation of Endosulfan was recorded in both the cases. The cell lysate was subjected to ammonium sulfate precipitation and dialysis, as it showed better results compared to the other fractions.

Ammonium sulfate was added to the crude cell lysate of Ps. aeruginosa to give $100 \%$ saturation. The solution was stirred at $4{ }^{\circ} \mathrm{C}$ for $30 \mathrm{~min}$ and centrifuged at $15,000 \times g$ for $20 \mathrm{~min}$; the precipitate was redissolved in $0.05 \mathrm{M}$ phosphate buffer of $\mathrm{pH} 6.8$.
Enzymatic degradation of Endosulfan was performed using the ammonium sulfate precipitated fraction. The ammonium sulfate precipitated sample of Ps. aeruginosa was dialysed overnight against $100 \mathrm{vol}$ of $0.05 \mathrm{M}$ phosphate buffer $(\mathrm{pH} 6.8)$ at $4{ }^{\circ} \mathrm{C}$. The dialysed sample was used for enzymatic degradation of Endosulfan. The protein content of ammonium sulfate precipitated and dialysed buffer wash fraction was determined by the Bradford's method (1976).

\section{Results}

\section{Repeated batch degradation}

From Fig. 3, it can be observed that Ca-alginate immobilized Ps. aeruginosa could be reused without affecting its degradation efficiency of $100 \%$ up to 5 cycles. By the end of the 10th cycle, the degradation efficiency decreased only by $2 \%$. Furthermore, by the end of the 15 th cycle, the degradation efficiency decreased to $95 \%$, and by the 20th cycle, it came down to $85 \%$. However, by the end of the 25 th cycle and the 30th cycle, the degradation efficiency decreased further to 76 and $68 \%$, respectively. By the end of the 35th cycle, $60 \%$ degradation efficiency was retained. The mechanical stability of the beads decreased gradually, as the cell leakage increased with cycles. A drastic reduction in the stability of the beads was noted by the 35th cycle. After 5 cycles, a cell leakage of $56 \mathrm{Cfu} / \mathrm{mL}$ was reported which increased with the number of cycles. A cell leakage of $642 \times 10^{4} \mathrm{Cfu} / \mathrm{mL}$ was recorded by the end of the 35th cycle. The results of cell leakage over time are indicated in Table 1.

\section{Continuous degradation of Endosulfan}

As shown in Fig. 4, $100 \%$ degradation was obtained with $2 \%$ concentration of Endosulfan up to $100 \mathrm{~mL} / \mathrm{h}$ flow rate (dt $36 \mathrm{~min}$ ) and with $4 \%$ concentration of Endosulfan up to $80 \mathrm{~mL} / \mathrm{h}$ flow rate $(\mathrm{dt} 108 \mathrm{~min}$ ). At $20 \mathrm{~mL} / \mathrm{h}$ flow rate (dt $324 \mathrm{~min}$ ), $100 \%$ degradation was recorded even up to $10 \%$ concentration of pesticide. At $40 \mathrm{~mL} / \mathrm{h}$ flow (dt $252 \mathrm{~min})$ rate, Ps. aeruginosa was able to show $100 \%$ degradation of Endosulfan up to $8 \%$ concentration. With $10 \%$ concentration of pesticide at $100 \mathrm{~mL} / \mathrm{h}$ flow rate $(\mathrm{dt}$ $36 \mathrm{~min}), 85 \%$ degradation of Endosulfan was recorded.

\section{LC-MS analysis}

The retention time for the Endosulfan standard was found to be 23.66. Compared to the chromatogram of Endosulfan control (Undegraded), the peak at retention time 23.62 reduced considerably in the chromatogram of Endosulfan 
Fig. 3 Repeated batch degradation of Endosulfan by Ca-alginate immobilized Ps. aeruginosa. Error bars represent the standard deviation of three replicates

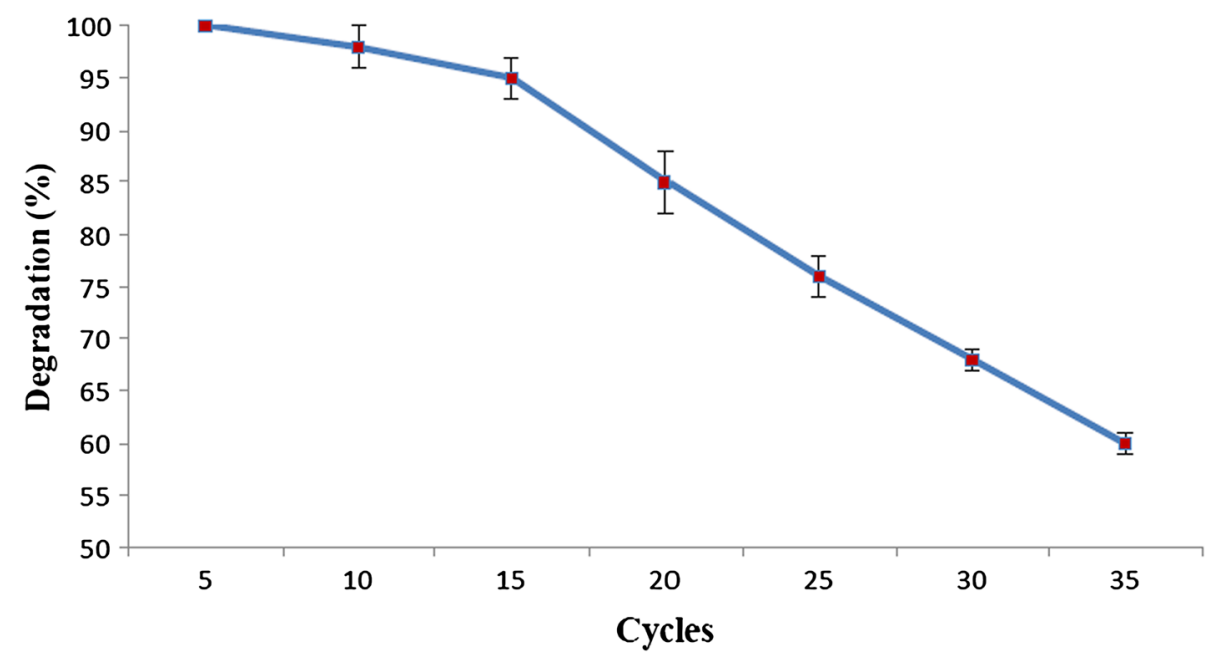

Table 1 Cell Leakage monitored every 5 cycles in repeated batch degradation

\begin{tabular}{ll}
\hline Cycle & Cell leakage $(\mathrm{Cfu} / \mathrm{mL})$ \\
\hline 5 & 56 \\
10 & 379 \\
15 & 775 \\
20 & $295 \times 10^{2}$ \\
25 & $518 \times 10^{2}$ \\
30 & $892 \times 10^{3}$ \\
35 & $642 \times 10^{4}$ \\
\hline
\end{tabular}

test sample (degraded) which indicates that only traces of Endosulfan are left in the test sample.

The $\mathrm{m} / \mathrm{z}$ value 405.43 , corresponding to the molecular weight of Endosulfan, is present in the mass spectrum of Endosulfan control (Fig. 5), but absent in the mass spectrum of Endosulfan test sample (Fig. 6).
The $m / z$ values corresponding to Endosulfan in the mass spectrum of Endosulfan control sample and mass spectrum of test sample according to the NIST standard (Fig. 7a) are listed in Table 2. In the mass spectrum of the Endosulfan test sample, $\mathrm{m} / \mathrm{z}$, peaks corresponding to Endosulfan lactone and endosulfan ether according to the NIST standard (Fig. $7 b, c)$ are seen which are listed in Table 3.

In the mass spectrum of Endosulfan test sample (Fig. 6), $\mathrm{m} / \mathrm{z}$ value of 356.14 , corresponding to molecular weight of Endosulfan lactone, is seen which is absent in the mass spectrum of Endosulfan control sample (Fig. 5). The base peak of 279 is stable which is seen in both test and control samples. Along with Endosulfan lactone, additional fragments of the metabolite, Endosulfan ether, according to the NIST standard (Fig. 7c), are also present in the mass spectrum of Endosulfan test present, which are also shown in Table 3. The base peak of Endosulfan ether with $\mathrm{m} /$ $z$ value of 69.06 is present in the mass spectrum of test sample (Fig. 6), but absent in the mass spectrum of control sample (Fig. 5).
Fig. 4 Continuous degradation of Endosulfan by immobilized Ps. aeruginosa. Error bars represent the standard deviation of three replicates

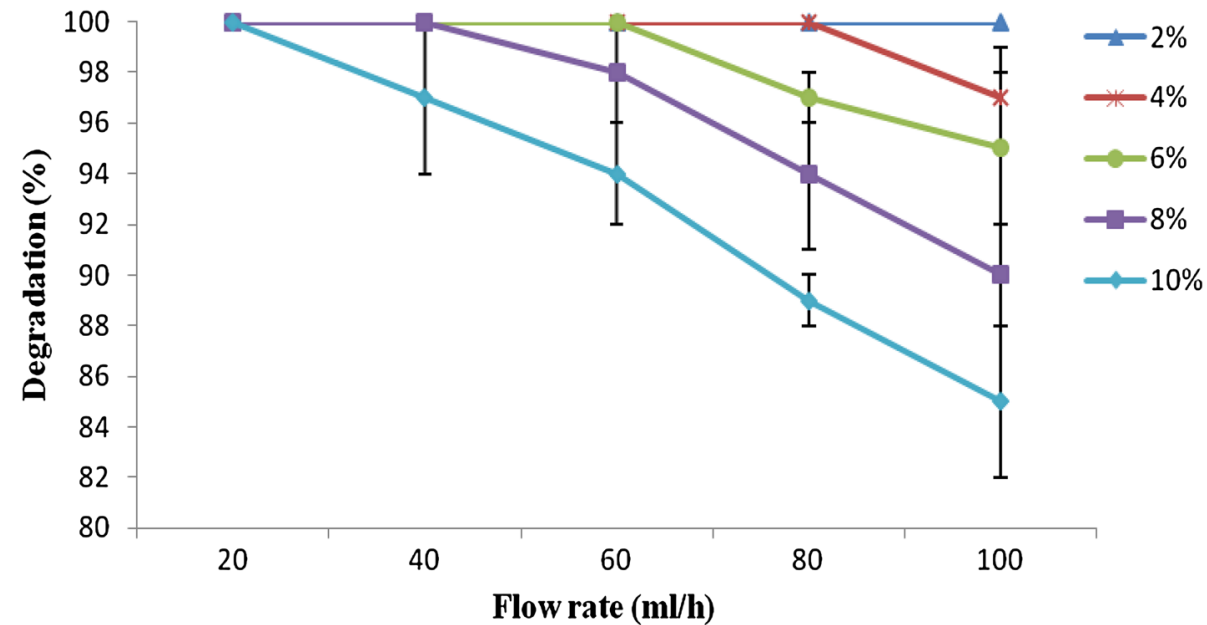




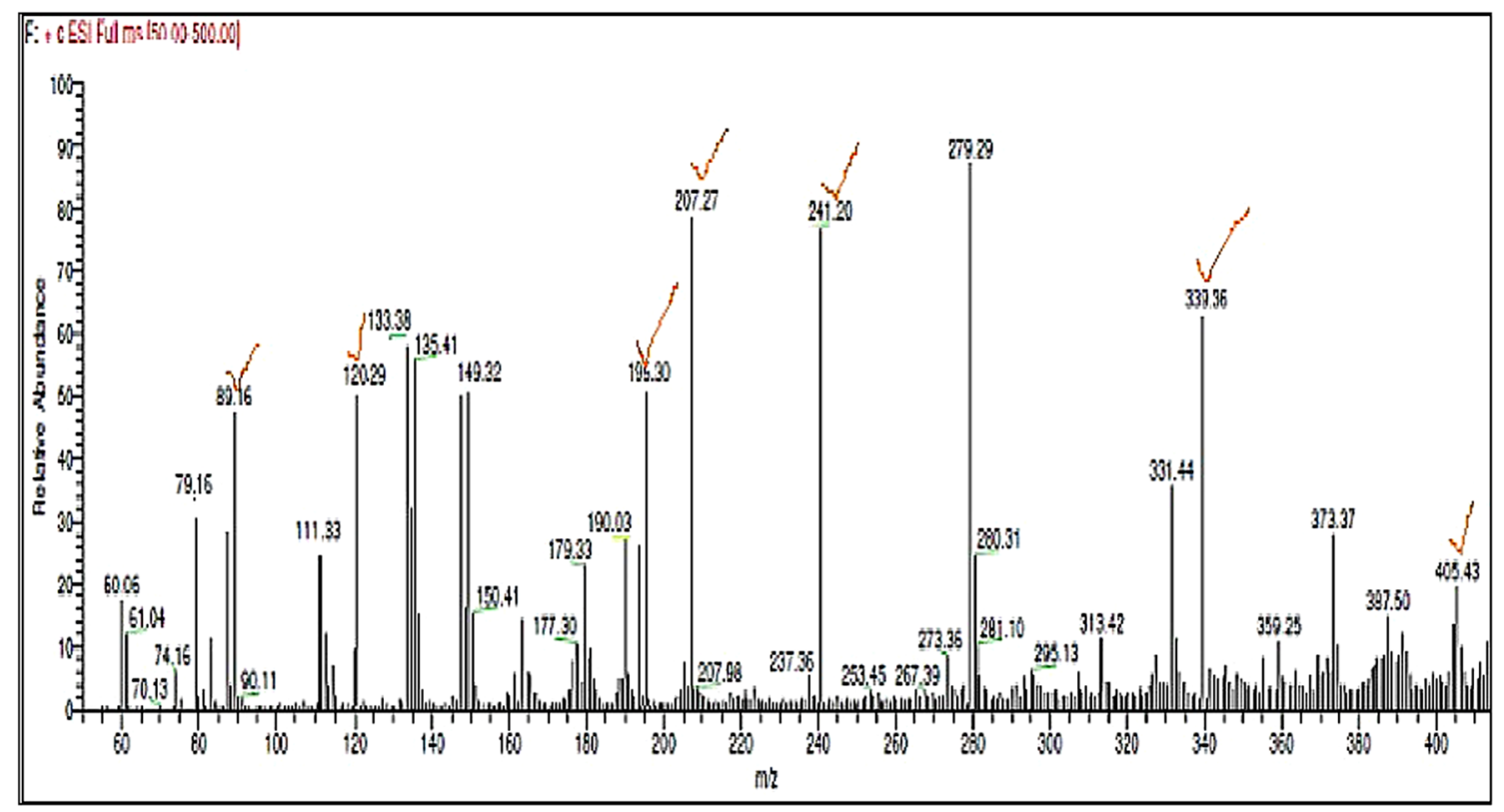

Fig. 5 Mass spectrum of Endosulfan control, Fragment ions corresponding to Endosulfan based on NIST spectrum of Endosulfan are ticked

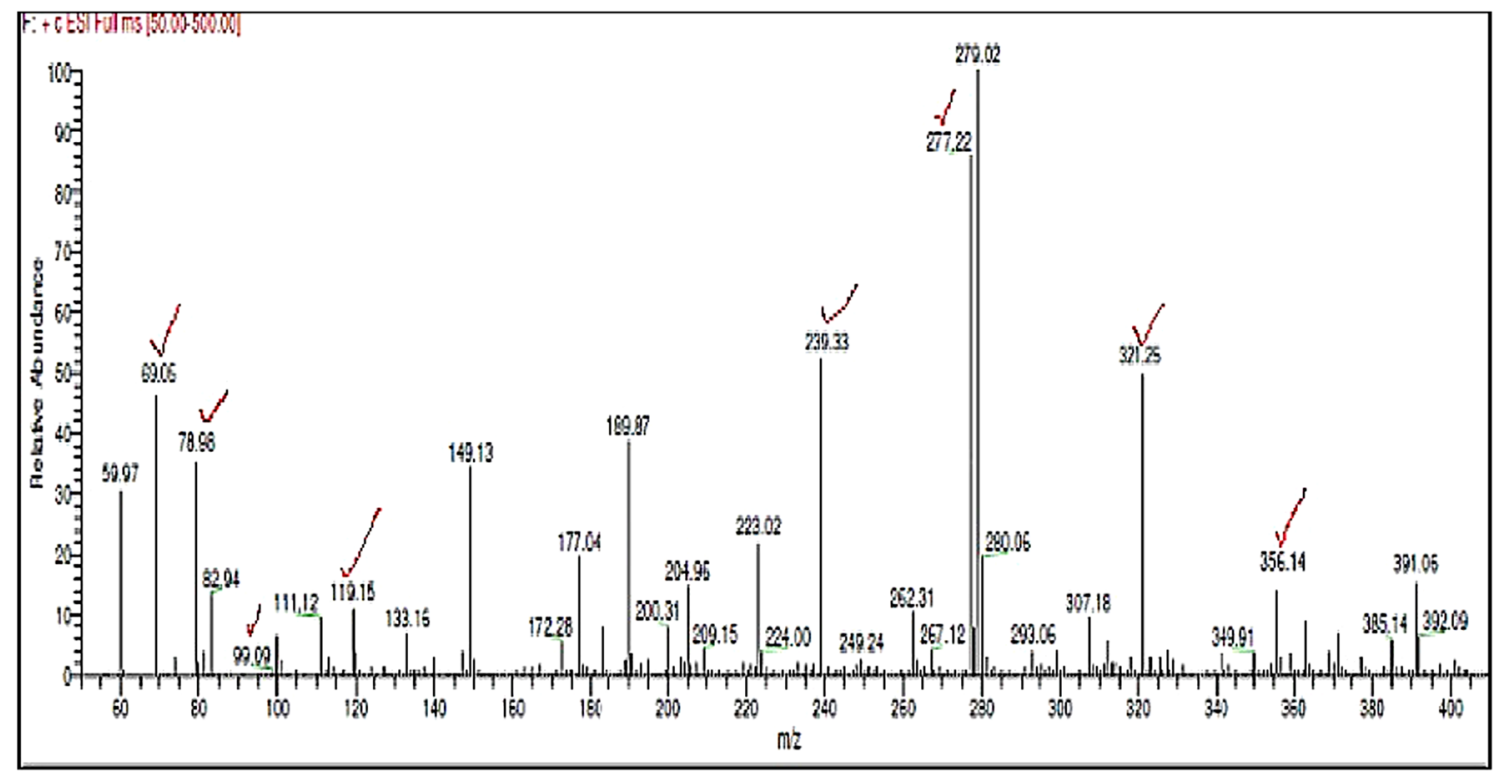

Fig. 6 Mass spectrum of Endosulfan test, Fragment ions corresponding to Endosulfan and its degradation products, i.e., Endosulfan lactone and Endosulfan ether, based on NIST spectra are ticked

\section{Plasmid isolation and plasmid curing}

On plasmid isolation and gel electrophoresis, it was observed that Ps. aeruginosa has a single band of plasmid. Curing experiment on Ps. aeruginosa was carried out to determine the presence of Endosulfan degrading genes on plasmid or on chromosome. With the increase in incubation period, the thickness of the plasmid band on agarose gel decreased.
As seen in Fig. 8, the thickness of the plasmid band reduced by day 3 and by day 4, the band disappeared indicating that the plasmid band was cured. Plasmid DNA cured cells of Ps. aeruginosa were able to grow on modified non-sulfur medium supplemented with Endosulfan as the sole source of carbon. This indicated that the genes responsible for the degradation Endosulfan are present on the chromosome and not on the plasmid. 

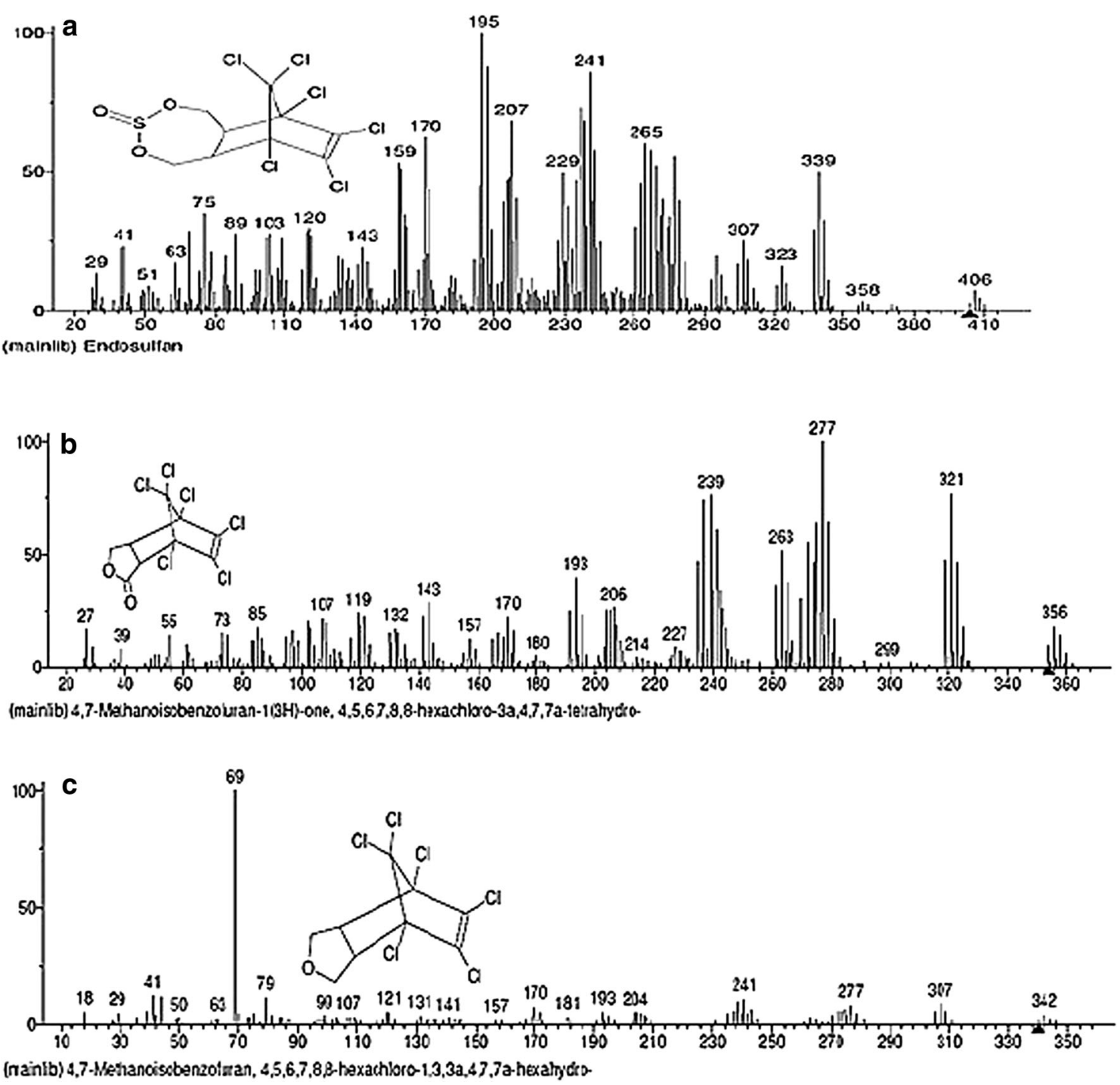

Fig. 7 NIST standard spectra of a Endosulfan, b Endosulfan Lactone, $\mathbf{c}$ Endosulfan ether (Contributor: Catalogue of mass spectra of pesticides, April, 1975; J. Freudenthal \& L. G. Gramberg, Nat'l Inst. of Public Health, The Netherlands)

Table $2 \mathrm{~m} / \mathrm{z}$ values of Endosulfan seen in the mass spectrum of Endosulfan control and test samples

\begin{tabular}{|c|c|}
\hline $\begin{array}{l}\mathrm{m} / \mathrm{z} \text { of Endosulfan in mass spectrum of Endosulfan control } \\
\text { according to NIST standards, as shown in Fig. } 7 \mathrm{a}\end{array}$ & $\begin{array}{l}\mathrm{m} / \mathrm{z} \text { of Endosulfan in mass spectrum of Endosulfan test } \\
\text { according to NIST standard, as shown in Fig. } 7 \text { a }\end{array}$ \\
\hline $\begin{array}{l}\text { 405.43, 339.96, 280.31, 279.29, 241.20, 207.27, 195.30, 120.29, } \\
\quad 119.22,111.33,89.16\end{array}$ & $\begin{array}{c}307.18,280.06,279.02,277.22,189.87 \\
119.15,111.12,99.09,82.94,78.98\end{array}$ \\
\hline
\end{tabular}

Table $3 \mathrm{~m} / \mathrm{z}$ values of degradation products of Endosulfan in the mass spectrum of Endosulfan test sample

\begin{tabular}{ll}
\hline $\begin{array}{l}m / z \text { of Endosulfan lactone } \\
\text { according to NIST standard, } \\
\text { as shown in Fig. 7b }\end{array}$ & $\begin{array}{l}m / z \text { of Endosulfan ether } \\
\text { according to NIST standard, } \\
\text { as shown in Fig. 7c }\end{array}$ \\
\hline $\begin{array}{l}356.14,321.25,277.22, \\
239.33,119.15\end{array}$ & $\begin{array}{r}279.02,277.22,267.12,209.15, \\
204.96,172.28,133.16,69.06\end{array}$
\end{tabular}

\section{Genomic DNA isolation and PCR analysis}

Genomic DNA from Ps. aeruginosa degrading Endosulfan was isolated, as shown in Fig. 9.

The culture was subjected to the PCR analysis. The results of PCR indicate that there is no amplified product of $\sim 1350 \mathrm{bp}$ expected for esd gene, in Ps. aeruginosa. However, there were some non-specific bands of 5000, 


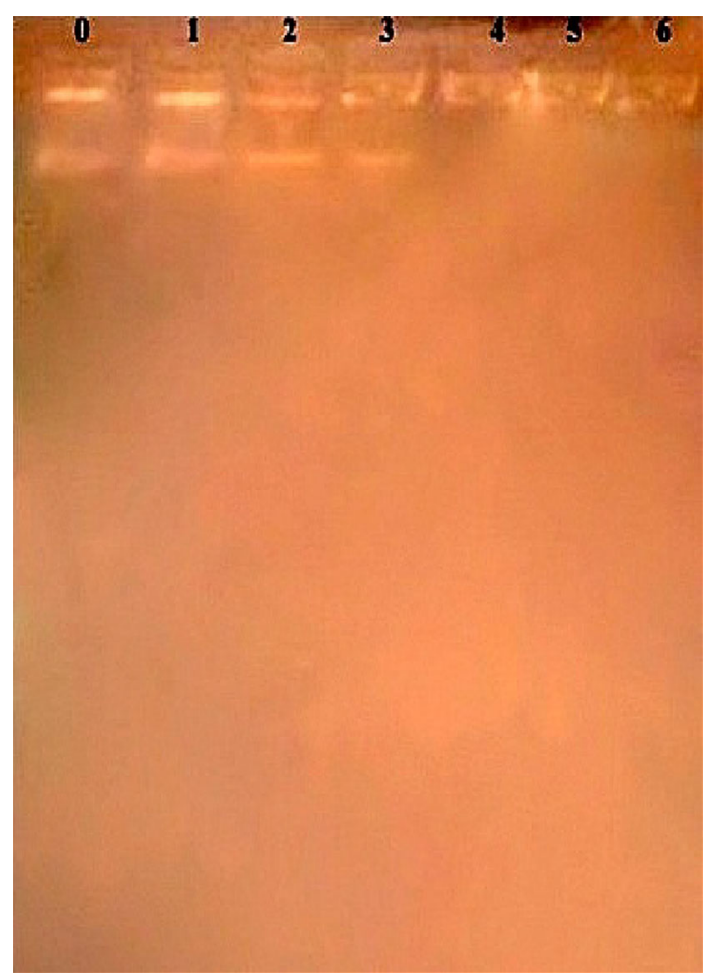

Fig. 8 Agarose gel electrophoresis of plasmid from Ps. aeruginosa subjected to curing. lane 0 indicates control sample (not treated with ethidium bromide), and lanes 1-6 indicate ethidium bromide treated bands of plasmid extracted from days 1-6

Fig. $90.5 \%$ Agarose gel electrophoresis of genomic DNA from $P$ s. aeruginosa

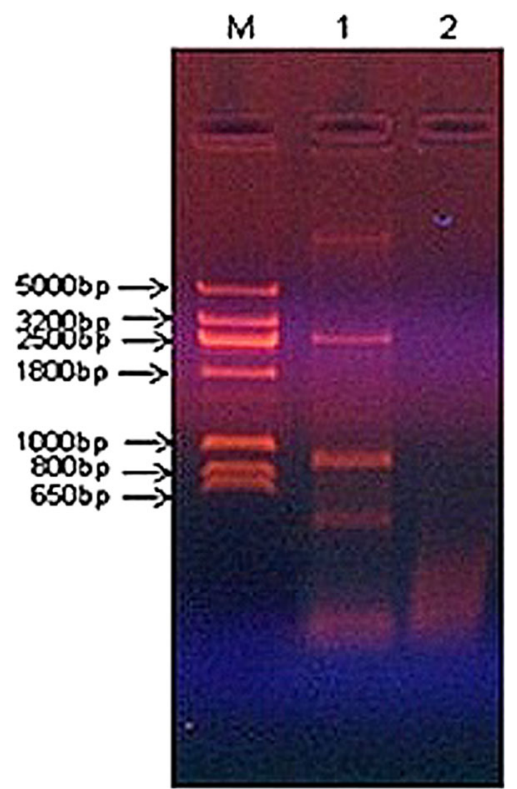

Fig. $100.8 \%$ Agarose gel electrophoresis of products of esd PCR. $M$ DNA molecular weight marker; 1 Ps. aeruginosa and 2 no template control

Table 4 Enzymatic degradation of Endosulfan with the supernatant, buffer wash, and cell lysate of Ps. aeruginosa

\begin{tabular}{lcc}
\hline $\begin{array}{l}\text { Enzyme } \\
\text { fraction }\end{array}$ & $\begin{array}{l}\text { Percent degradation } \\
\text { of Endosulfan }\end{array}$ & $\begin{array}{l}\text { Protein content } \\
(\mathrm{mg} / \mathrm{mL})\end{array}$ \\
\hline Supernatant & $3 \pm 1$ & $0.09 \pm 0.01$ \\
Buffer wash & $8.16 \pm 0.76$ & $0.343 \pm 0.025$ \\
Cell lysate & $15 \pm 2$ & $0.663 \pm 0.03$ \\
\hline
\end{tabular}

Values are a mean of three replicates \pm SD

3200, 2500, 1800, 1000, 800, and $650 \mathrm{bp}$. These bands could be amplified products of genes other than esd gene (Fig. 10).

\section{Enzymatic degradation of Endosulfan}

The results of the enzymatic degradation of Endosulfan with the supernatant, buffer wash, and cell lysate of $P S$. aeruginosa are presented in Table 4.

Highest degradation of Endosulfan was recorded with crude cell lysate. Lesser degradation of Endosulfan was recorded with buffer wash and a least degradation with cell free supernatant. This indicated that the enzymes involved in the degradation of Endosulfan are intracellular. 
Table 5 Enzymatic degradation of Endosulfan by partially purified enzyme fractions

\begin{tabular}{lcc}
\hline Enzyme fraction & $\begin{array}{l}\text { Percent } \\
\text { degradation }\end{array}$ & $\begin{array}{l}\text { Protein content } \\
(\mathrm{mg} / \mathrm{mL})\end{array}$ \\
\hline $\begin{array}{l}\text { Cell lysate of } P \text { s. aeruginosa } \\
\begin{array}{l}\text { After ammonium sulfate } \\
\text { precipitation }\end{array}\end{array}$ & $15 \pm 2$ & $0.663 \pm 0.03$ \\
\begin{tabular}{l} 
After dialysis \\
\hline
\end{tabular} & $45 \pm 1.53 \pm 1$ & $0.358 \pm 0.025$ \\
\end{tabular}

Values are a mean of three replicates $\pm \mathrm{SD}$

When cell lysate of Ps. aeruginosa was subjected to ammonium sulfate precipitation, there was an increase in the degradation of Endosulfan. Degradation of Endosulfan increased further after dialysis of ammonium sulfate precipitated sample (Table 5).

\section{Discussion}

In the current study, when repeated batch degradation study was carried out, immobilized cells of Ps. aeruginosa were able to show $60 \%$ degradation of Endosulfan at the end of the 35 th cycle with a cell leakage of $642 \times 10^{4} \mathrm{Cfu} / \mathrm{mL}$. In similar studies, Endosulfan degrading ability of Klebsiella oxytoca KE-8 immobilized by entrapment with activated carbon was investigated by Jo et al. (2010). Activated carbon with immobilized cells $K$. Oxytoca KE-8 that had been used for one degradation activity was stored for 1, 15, and 30 days at $4{ }^{\circ} \mathrm{C}$. Endosulfan degradation activity after one month duration was $81 \%$, compared to $98 \%$ before storage.

Immobilized cells have been used for the degradation of various pesticides. In the current study, a degradation of $100 \%$ was obtained with $2 \%$ concentration of Endosulfan up to $100 \mathrm{~mL} / \mathrm{h}$ flow rate and with $4 \%$ concentration of Endosulfan up to $80 \mathrm{~mL} / \mathrm{h}$ flow rate. With $10 \%$ concentration of pesticide at $100 \mathrm{~mL} / \mathrm{h}$ flow rate, $85 \%$ degradation of Endosulfan was recorded. Recycle packed bed column mode and continuous packed bed column mode for Endosulfan degradation were also studied by Jo et al. (2010). The effect of the hydraulic retention time (from 25 to $300 \mathrm{~min}$ ) on the performance of bioreactor was studied by them with variation in the influent flow rate. The immobilized cells in a laboratory scale pack bed column with support beads were able to degrade Endosulfan completely in defined minimal salt medium at a maximum rate of $129.6 \mu \mathrm{g} / \mathrm{mL}$ per day, under optimum operation condition.

Column studies with calcium alginate entrapped cells of Pseudomonas fluorescens was carried out by Jesitha et al. (2015). They reported that broth mineral medium was supplemented with $350 \mu \mathrm{g} / \mathrm{L}$ endosulfan and was passed through the column at the rate of $0.59 \mathrm{~mL} / \mathrm{min}$ and the column was operated for 18 days. At this rate, the hydraulic retention time reported was $300 \mathrm{~min}$. The studies reported that the integrity of the beads was maintained.

Similar studies were also carried out by Yañez-Ocampo et al. (Yáñez-Ocampo et al. 2011) using a tezontle-packed up-flow reactor (TPUFR) with an immobilized bacterial consortium for biological treatment of methyl-parathion and tetrachlorvinphos. In the bioreactor, four flow rates $(0.936,1.41,2.19$, and $3.51 \mathrm{l} / \mathrm{h})$ and four hydraulic residence times $(0.313,0.206,0.133$, and $0.083 \mathrm{~h})$ were evaluated. With an operating time of $8 \mathrm{~h}$ and a flow of $0.936 \mathrm{l} /$ $\mathrm{h}$, they obtained $75 \%$ efficiency in the removal of methylparathion and tetrachlorvinphos.

To create an E. coli expression construct, Sutherland et al. (2002a) amplified the esd gene by PCR using pYUB415-Apa3 as the template. However, in the current study, when the genome of $P$ s. aeruginosa was subjected to PCR for the amplification of esd gene, there was no amplified product of $\sim 1350 \mathrm{bp}$ expected to be involved in the oxidative pathway of degradation of Endosulfan in the culture. The absence of $e s d$ gene product could mean that ese gene may be present in Ps. aeruginosa. A gene, ese, encoding an enzyme capable of degrading both isomers of Endosulfan and endosulfate was isolated from Arthrobacter by Weir et al. (2006). The enzyme belongs to the twocomponent flavin-dependent mono-oxygenase family, whose members require reduced flavin for activity. An overview of aerobic endosulfan degradation by bacteria and fungi, and a summary of recent advances and prospects in this research field were given by Kataoka and Takagi (2013). Pathway summarized by the authors indicated difference in products accumulated when the degradation occurs with the involvement of ese and esd genes. According to the authors, ese indicated the pathway described by Weir et al. (2006) involving ese mono-oxygenase, whereas esd indicated the pathway described by Sutherland et al. (2002b) involving esd mono-oxygenase.

According to Seralathan et al., only the human CYP (cytochrome P450) enzymes and two bacterial genes (esd and ese) have been reported for endosulfan biotransformation (Kahli et al. 2006; Sean et al. 2008; Sutherland et al. 2002a). Thus, the genetic information on endosulfan metabolism is scanty, and it is a major setback for endosulfan biotransformation.

The other possibility in our present study could be the absence of both esd and ese gene products. In similar studies, PCR primers pairs coding for flavin mononucleotide-dependent mono-oxygenase present in a Mycobacterium spp. (esd) and mono-oxygenase of Arthrobacter spp. (ese) were employed by Bajaj et al. (2010) to amplify 1347-bp and 1428-bp, respectively. Genomic DNA of IITR01 as a template with the primer, 


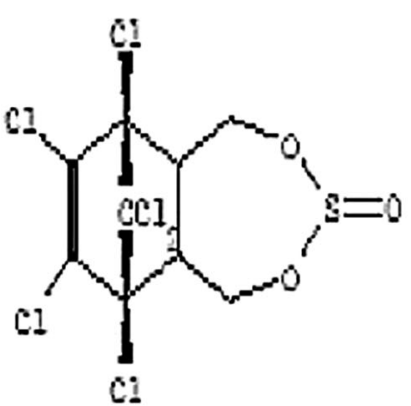

Endosulfan

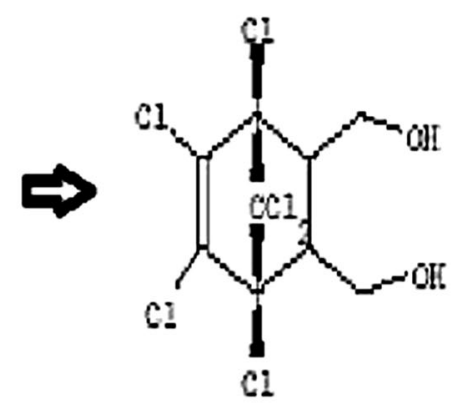

Endosulfan diol

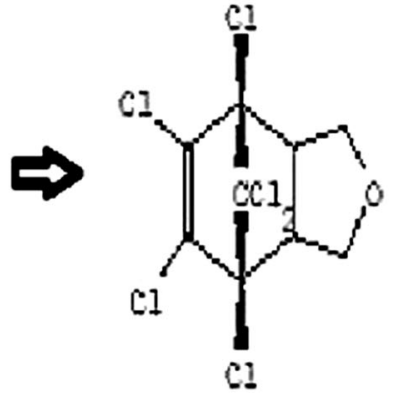

Endosulfan ether

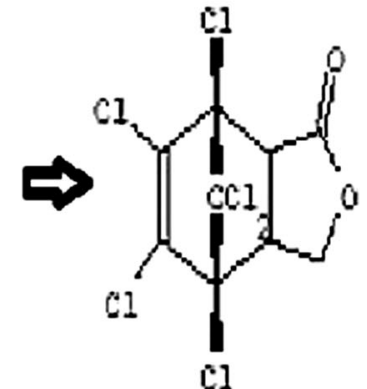

Endosulfan Lactone

Fig. 11 Proposed pathway of Endosulfan degradation

pairs (esd 1 and $e s d 2$ ) internal to the $e s d$ gene did not yield the expected gene product size 780 and 620 , respectively; instead, a fragment of $600 \mathrm{bp}$ was obtained from the genomic DNA of strain IITR01. The ese mono-oxygenase, which is $1428 \mathrm{bp}$, was also found to be absent, as they could obtain a non-specific PCR product of $682 \mathrm{bp}$. Later studies by them revealed that the nucleotide sequences belonged to transporter protein family.

Our current investigation indicates the fact that Endosulfan degradation by the organism is probably by the nonoxidative, alternate pathway. This observation is supported by the fact that predicted products of Endosulfan degradation in the current study by Ps. aeruginosa are Endosulfan ether and Endosulfan lactone, which are the products seen in the non-oxidative pathway of Endosulfan degradation. Although the first intermediate, endosulfan diol was not detected by us, since further metabolites were detected, such a pathway is proposed. The absence of the metabolites endosulfan sulfate and Endosulfan mono alcohol further confirms the presence of non-oxidative pathway. The nonoxidative pathway shows the presence of relatively nontoxic metabolites compared to the parent compound and the metabolites, such as endosulfan sulfate, seen in other pathways. Similar results were obtained by $\mathrm{Yu}$ et al. (2012). In their studies, Endosulfan diol and Endosulfan ether were detected as major metabolites, which indicated that the bacterium Stenotrophomonas spp. LD-6 might degrade Endosulfan by a non-oxidative pathway. They reported that $100 \mathrm{mg} / \mathrm{L}$ Endosulfan was completely degraded within 10 days, and Endosulfan diol and Endosulfan ether were detected as major metabolites. Kumar et al. (2007), also reported that the hydrolysis of endosulfan in some bacteria (Pseudomonas aeruginosa and Burkholderia cepaeia) yields the less toxic metabolite endosulfan diol. The diol can be converted to endosulfan ether (Hussain et al. 2007) or endosulfan hydroxyether (Lee et al. 2003) and then endosulfan lactone (Awasthi et al. 2003). Hydrolysis of endosulfan lactone yields endosulfan hydroxycarboxylate (Walse et al. 2003).
Based on our degradation studies, LC-MS of degradation products, and PCR analysis, the non-oxidative pathway for degradation of Endosulfan was predicted, which is shown in Fig. 11. Here, it is proposed that Endosulfan, which is a cyclodiene organo-chlorine, is converted to a less toxic intermediate, the endodiol form, and Endosulfan diol, which is further converted to Endosulfan ether and then to Endosulfan lactone. This pathway could involve the enzymes, such as hydrolases and mono-oxygenases, which need to be further studied. Similar results have been reported by Li et al. (2009) that the formation of Endosulfan diol and Endosulfan ether as the major metabolites of Endosulfan degradation by Achromobacter xylosoxidans CS5 and suggested a nonoxidative pathway of degradation. Bajaj et al. (2010) reported the formation of hydroxylated products ES diol, Endosulfan ether, and Endosulfan lactone by a Pseudomonas spp. strain IITR01.

Endosulfan degradation was better with cell lysate of $P$ s. aeruginosa compared to buffer wash and supernatant. Similar results were obtained by Yu et al. (2012), who demonstrated that the cell crude extract of strain LD-6, Stenotrophomonas spp. could metabolize Endosulfan rapidly and degradative enzymes were intracellularly distributed.

\section{Conclusion}

Thus, it can be concluded that Ca-alginate immobilized cells of Ps. aeruginosa were efficient in degrading Endosulfan, and the Ca-alginate immobilized cells were stable for a long duration. Endosulfan was degraded by non-oxidative pathway, and Endosulfan ether and Endosulfan lactone were the predicted products of degradation. Furthermore, it was demonstrated that genes involved in the degradation of Endosulfan were present on the chromosome, and the enzymes involved in its degradation were intracellular.

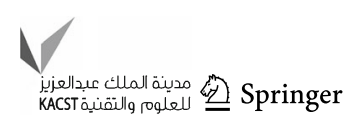


Acknowledgments The authors thank I.I.H.R., Bangalore, for the pesticide analytical standard and Prof. Mohan Reddy K., University of Petroleum and Energy Studies, Dehradun, for his valuable inputs in interpreting the LC-MS spectra.

\section{Compliance with ethical standards}

Conflict of interest The authors declare that they have no conflict of interest in the publication.

Open Access This article is distributed under the terms of the Creative Commons Attribution 4.0 International License (http:// creativecommons.org/licenses/by/4.0/), which permits unrestricted use, distribution, and reproduction in any medium, provided you give appropriate credit to the original author(s) and the source, provide a link to the Creative Commons license, and indicate if changes were made.

\section{References}

Abdel-Razek MAS, Folch-Mallol JL, Perezgasga-Ciscomani L, Sánchez Salinas E, Castrejón-Godínez ML, Ortiz-Hernández ML (2013) Optimization of methyl parathion biodegradation and detoxification by cells in suspension or immobilized on tezontle expressing the opd gene. J Environ Sci Health Part B 48(6):449-461

Awasthi N, Singh AK, Jain RK, Khangarot BS, Kumar A (2003) Degradation and detoxification of endosulfan isomers by a defined co-culture of two Bacillus strains. Appl Microbiol Biotechnol 62(2-3):279-283

Bajaj A, Pathak A, Mudiam M, Mayilraj S, Manickam N (2010) Isolation and characterization of a Pseudomonas sp. strain IITR01 capable of degrading $\alpha$-endosulfan and endosulfan sulfate. J Appl Microbiol 109(6):2135-2143

Bettman H, Rehm H (1984) Degradation of phenol by polymer entrapped microorganisms. Appl Microbiol Biotechnol 20(5):285-290

Bradford MM (1976) A rapid sensitive method for the quantitation of microgram quantities of protein utilizing the principle of proteindye binding. Anal Biochem 72:248-252

Chaudhuri K, Selvaraj S, Pal AK (1999) Studies on the genotoxicology of Endosulfan in bacterial system. Mutat Res 439:63-67

Goebel H (1982) Chemical and physical properties of Endosulfan and its degradation products. Residue Rev 83:8-28

Ha J, Engler CR, Wild JR (2009) Biodegradation of coumaphos, chlorferon, and diethylthiophosphate using bacteria immobilized in Ca-alginate gel beads. Bioresour Technol 100(3):1138-1142

Hoechst (1990) Thiodan product manual, up to date on properties and behavior. Hoechst Aktiengese llschaft Marketing Agriculture, Hoechst Ltd.: Australia

Hussain S, Arshad M, Saleem M, Khalid A (2007) Biodegradation of alpha- and beta-endosulfan by soil bacteria. Biodegradation 18(6):731-740

JenNi K, Pasternak J, Wan MT, Buday C, Schroeder G, Van Aggelen G (2005) Toxicity of $\alpha-, \beta-,(\alpha+\beta)$-endosulfan and their formilated and degradation products to Daphnia magna, Hyalella azteca, Oncorhynchus mykiss, Oncorhynchus kisutch, and biological implications in streams. Environ Toxicol Chem 24:1146-1154

Jesitha K, Nimisha KM, Manjusha CM, Harikumar PS (2015) Biodegradation of Endosulfan by Pseudomonas fluorescens. Environ Process 2:225-240

Jianlong W, Xiangchun Q, Liping H, Yi Q, Hegemann W (2002) Microbial degradation of quinoline by immobilized Cells of Burkholderia pickettii. Wat Res 36:2288-2296
Jo M, Lee J, Kim J, Sohn H, Jeon C, Choi C, Kwon G (2010) Biodegradation of Endosulfan by Klebsiella oxytoca KE-8 immobilized on activated carbon. Korean J Environ Agric 29(2):176-183

Kahli MW, Sutherland TD, Irene H, Robyn JR, John GO (2006) A single monooxygenase, Ese, is involved in the metabolism of the organochlorides endosulfan and endosulfate in an Arthrobacter sp. Appl Environ Microbiol 72(5):3524-3530

Karigar C, Mahesh A, Nagenahalli M, Yun DJ (2006) Phenol degradation by immobilized cells of Arthrobacter citreus. Biodegradation 17:47-55

Kataoka R, Takagi K (2013) Biodegradability and biodegradation pathways of endosulfan and endosulfan sulfate. Mini-review. Appl Microbiol Biotechnol 97(8):3285-3292

Katayama A, Matsumura F (1993) Degradation of organochlorine pesticides particularly endosulfan by Trichoderm harzianum. Environ Toxicol Chem 12:1059-1065

Kim JW, Rainina EI, Mulbry WW, Engler CR, Wild JR (2002) Enhanced-rate biodegradation of organophosphate neurotoxins by immobilized non growing bacteria. Biotechnol Prog 18:429-436

Kullman SW, Matsumura F (1996) Metabolic pathway utilized by Phenerochete chrysosporium for degradation of the cyclodine pesticide Endosulfan. Appl Environ Microbiol 62:593-600

Kumar K, Devi SS, Krishnamurthi K, Kanade GS, Chakrabarti T (2007) Enrichment and isolation of endosulfan degrading and detoxifying bacteria. Chemosphere 68(2):317-322

Lee N, Skerritt JH, McAdam DP (1995) Hapten synthesis and development of ELISAs for the detection of Endosulfan in water and soil. J Agric Food Chem 43:1730-1739

Lee SE, Kim JS, Kennedy IR, Park JW, Kwon GS, Koh SC, Kim JE (2003) Biotransformation of an organochlorine insecticide, endosulfan, by Anabaena species. J Agric Food Chem 51(5):1336-1340

Li W, Dai Y, Xue B, Li Y, Peng X, Zhang J, Yan Y (2009) Biodegradation and detoxification of endosulfan in aqueous medium and soil by Achromobacter xylosoxidans strain CS5. J Hazard Mater 167(1-3):209-216

Manohar S, Karegoudar TB (1998) Degradation of naphthalene by cells of Pseudomonas sp. strain NGK 1, immobilized in alginate, agar and polyacrylamide. Appl Microbiol Biotechnol 49:785-792

Manohar S, Kim CK, Karegoudar TB (2001) Enhanced degradation of naphthalene by immobilization of Pseudomonas sp. strain NGK1 in polyurethane foam. Appl Microbiol Biotechnol 55:311-316

Mansee AH, Chen W, Mulchandani A (2005) Detoxification of the organophosphate nerve agent coumaphos using organophosphorus hydrolase immobilized on cellulose materials. J Ind Microbiol Biotechnol 32:554-560

Murakami NT, Kirimura K, Kino K (2003) Degradation of dimethyl sulfoxide by the immobilized cells of Hyphomicrobium denitrificans WU-K217. J Biosci Bioeng 15:199-204

Pai SL, Hsu YL, Chong NM, Sheu CS, Chen CH (1995) Continuous degradation of phenol by Rhodococcus sp. immobilized on granuar activated carbon and in calcium alginate. Bioresour Technol 51:37-42

Paul V, Balasubramaniam E (1997) Effect of single and repeated administration of Endosulfan on behaviour and its interaction with centrally acting drugs in experimental animals: a mini review. Environ Toxicol Pharmacol 3:151-157

Pazarlioglu NK, Telefoncu A (2005) Biodegradation of phenol by Pseudomonas putida immobilized on activated pumice particles. Process Biochem 40:1807-1814

Rahman RNZA, Ghazali FM, Salleh AB, Basri M (2006) Biodegradation of hydrocarbon contamination by immobilized bacterial cells. J Microbiol 44:354-359 
Raju J, Gupta VK (1991) A simple spectrophotometric determination of endosulfan in river water and soil. Fresenius J Anal Chem 339:431-433

Richins RD, Mulchandani A, Chen W (2000) Expression, immobilization, and enzymatic characterization of cellulose-binding domain-organophosphorus hydrolase fusion enzymes. Biotechnol Bioeng 69(6):591-596

Sambrook J, Fritsch EF, Maniatis T (Cold Spring Harbor, NY: 1989). Molecular cloning, a laboratory manual, 2nd edn. Cold Spring Harbor Laboratory Press, p 1.29

Sambrook J, Russell DW (2001) Molecular cloning: a laboratory manual, 3rd edn. Cold Spring Harbor Laboratory Press, Cold Spring Harbor, New York

Sean E, Manisha I, Matthew DK, Evan DK (2008) Molecular characterization of CYP2B6 substrates. Curr Drug Metab 9(5):363-373

Shivaramaiah HM, Kennedy IR (2006) Biodegradation of Endosulfan by a soil bacterium. J Environ Sci Health Part B 41:895-905

Siddique T, Okeke BC, Arshad A, Frankenberger WT Jr (2003) Enrichment and isolation of endosulfan-degrading microorganisms. J Environ Qual 32:47-54

Sinha N, Narayan R, Saxena DK (1997) Effect of Endosulfan on testis of growing rats. Bull Environ Contam Toxicol 58:79-86

Sutherland TD, Horne I, Russell RJ, Oakeshott JG (2002a) Gene cloning and molecular characterization of a two-enzyme system catalyzing the oxidative detoxification of beta-endosulfan. Appl Environ Microbiol 68(12):6237-6245

Sutherland TD, Horne I, Harcourt RL, Russell RJ, Oakeshott JG (2002b) Isolation and characterization of a Mycobacterium strain that metabolizes the insecticide endosulfan. J Appl Microbiol 93(3):380-389

Venugopal NVS, Sumalatha B (2011). 2nd International conference on Environmental Science and Technology. IPCBEE, IACSIT Press, Singapore.vol 6
Verma A, Ali D, Farooq M, Pant AB, Ray RS, Hans RK (2011) Expression and inducibility of endosulfan metabolizing gene in Rhodococcus strain isolated from earthworm gut microflora for its application in bioremediation. Bioresour Technol 102:2979-2984

Vijayalakshmi P, Usha MS (2012). Degradation of Endosulfan by free cells and Calcium-alginate immobilized cells of Pseudomonas spp. The proceedings of International Conference on Biologically active molecules, at Gandhigram Rural Institute-Deemed University, Tamilnadu. ISBN: 978-93-82062-03-5

Walse SS, Scott GI, Ferry JL (2003) Stereoselective degradation of aqueous endosulfan in modular estuarine mesocosms: formation of endosulfan $\gamma$-hydroxycarboxylate. $\mathrm{J}$ Environ Monit 5(3):373-379

Weir KM, Sutherland TD, Horne I, Russell RJ, Oakeshott JG (2006) A single monooxygenase, ese, is involved in the metabolism of the organochlorides Endosulfan and Endosulfate in an Arthrobacter sp. Appl Environ Microbiol 72:3524-3530

Vijaiyan SG, Rajam A (2013) Degradation of Endosulfan using Pseudomonas sp. ED1 isolated from pesticide contaminated soil. J Acad Ind Res 2(3):170-175

Yáñez-Ocampo G, Sánchez-Salinas E, Ortiz-Hernández ML (2011) Removal of methyl parathion and tetrachlorvinphos by a bacterial consortium immobilized on tezontle-packed up-flow reactor. Biodegradation 22(6):1203-1213

Yu FB, Ali SW, Sun JY, Luo LP (2012) Isolation and characterization of an Endosulfan-degrading strain, Stenotrophomonas spp. LD6 , and its potential in soil bioremediation. Pol J Microbiol 61(4):257-262 